\title{
DETERMINAN STATUS PENGGUNAAN METODE KONTRASEPSI JANGKA PANJANG DI INDONESIA TAHUN 2017
}

The Determinant of the Status of Using Long-Term Contraception Method in Indonesia in 2017

\author{
Shafiyah Asy Syahidah' ${ }^{1}$, Budyanra Budyanra² \\ 1,2Politeknik Statistika STIS \\ Jalan Otto Iskandardinata nomor 64C, Jakarta Timur \\ E-mail: 16.9418@stis.ac.id
}

\begin{abstract}
ABSTRAK
Indonesia saat ini masih memiliki berbagai masalah kependudukan. Tingginya angka fertilitas dan laju pertumbuhan penduduk yang tidak seiring dengan peningkatan kualitas penduduk akan berimbas pada beratnya beban pemerintah dalam mensejahterakan rakyatnya. Berbagai cara telah diupayakan pemerintah guna menekan angka fertilitas, salah satunya melalui program Keluarga Berencana (KB) dengan penggunaan alat/cara kontrasepsi. Dari berbagai jenis metode, Badan Kependudukan dan Keluarga Berencana Nasional (BKKBN) mengemukakan bahwa Metode Kontrasepsi Jangka Panjang (MKJP) merupakan metode kontrasepsi paling efektif dengan tingkat keberhasilan melebihi 95 persen. Namun, hasil Survei Demografi dan Kesehatan Indonesia (SDKI) tahun 2017 menyatakan hanya 13,2 persen wanita usia subur (WUS) berstatus kawin yang menggunakan MKJP, padahal target paruh waktu Rencana Pembangunan Jangka Menengah Nasional (RPJMN) pada 2016 harus mencapai 21,1 persen. Melihat rendahnya capaian tersebut, penelitian ini bertujuan untuk menganalisis determinan status penggunaan MKJP di Indonesia tahun 2017 menggunakan regresi logistik biner yang mengakomodir penimbang survei. Data sekunder diperoleh dari raw data hasil SDKI 2017. Hasil analisis deskriptif menunjukkan bahwa secara umum hanya sebesar 21,05 persen pengguna MKJP di Indonesia tahun 2017. Selanjutnya, berdasarkan hasil analisis inferensia, diperoleh variabel umur WUS, tingkat pendidikan WUS, umur kawin pertama WUS, Anak Lahir Hidup, akses informasi $K B$, pengambil keputusan ber-KB, umur suami, dan tingkat pendidikan suami signifikan memengaruhi status penggunaan MKJP pada penelitian ini.
\end{abstract}

Kata kunci: fertilitas, metode kontrasepsi jangka panjang, SDKI, penimbang, regresi logistik biner

\section{ABSTRACT}

Indonesia currently still has various population problems. The high fertility rate and population growth rate which are not in line with the increase in population quality will have an impact on the burden of the government in the welfare of its people. Various ways have been attempted by the government to reduce fertility rate, one of which is through the family planning program using contraceptive methods. Badan Kependudukan dan Keluarga Berencana Nasional (BKKBN) suggests that the Long-Term Contraception Method (LTCM) is the most effective method of contraception with a success rate above 95 percent. However, the result of the 2017 Indonesian Demographic and Health Survey (IDHS) states that only 13.2 percent of women of childbearing age who currently married using LTCM, even though the national mediumterm development plan (RPJMN) in 2016 must reach 21.1 percent. Seeing the low performance of it, this study aims to analyze the determinants of the status of using LTCM in Indonesia in 2017 using binary logistic regression which accommodates survey weight. Secondary data were obtained from the raw data of IDHS 2017. The results of the descriptive analysis showed only 21.5 percent of LTCM users in Indonesia in 2017. Furthermore, based on inference analysis, the women age, women education, parity, access to family planning information, family planning decisions, husband age, and husband education significantly influence the status of LTCM use in this study.

Keywords: fertility, long-term contraception method, IDHS, weight, binary logistic regression.

\section{PENDAHULUAN}

Sebagai negara peringkat keempat dengan jumlah penduduk terbesar di dunia, Indonesia memiliki berbagai masalah kependudukan yang cukup banyak ketimbang negara-negara dengan peringkat di atasnya, yaitu secara berturut-turut Amerika Serikat, India, dan Tiongkok. Indonesia 
masih memiliki laju pertumbuhan penduduk yang tergolong tinggi, yakni sebesar 1,1 persen per tahun pada 2005-2010 (International Conference on Population and Development, 2012). Pada periode yang sama, negara-negara berkembang dengan jumlah penduduk yang cukup besar di Kawasan Asia Tenggara, sudah memiliki laju pertumbuhan penduduk yang lebih rendah. Tercatat bahwa Thailand dengan jumlah penduduk terbanyak keempat di Kawasan Asia Tenggara hanya memiliki laju pertumbuhan penduduk sebesar 0,7 persen per tahun. Sama halnya dengan Thailand, laju pertumbuhan penduduk Myanmar di urutan kelima dengan jumlah penduduk terbanyak di Kawasan Asia Tenggara sudah mencapai 0,7 persen per tahun.

Pertambahan jumlah penduduk yang tidak seiring dengan peningkatan kualitas penduduk akan berimbas pada beratnya beban pemerintah dalam mensejahterakan rakyatnya. Dirilis oleh United Nations Development Programme (UNDP) mengenai Human Development Index (HDI), pada 2019 Indonesia hanya mencapai peringkat ke-111 dunia dengan nilai HDI sebesar 0,71 (UNDP, 2020). Semakin tinggi nilai HDI memberi arti semakin baik kualitas penduduk di suatu negara. Pada tahun yang sama, nilai HDI Indonesia terbilang berjarak cukup jauh dengan Thailand yang memiliki nilai 0,765. Bahkan, Malaysia sudah memiliki nilai HDI sebesar 0,804 (UNDP, 2020).

Ukuran kesejahteraan suatu negara yang dinilai melalui total output atau Produk Domestik Bruto (PDB) dengan pendekatan Purchasing Power Parity (PPP) menunjukkan PDB PPP per kapita Indonesia hanya berkisar di sekitar nilai 11 ribu dolar Amerika Serikat, sementara Thailand sudah memiliki nilai PDB PPP per kapita dengan nilai setengah kali lebih tinggi dari nilai PDB PPP per kapita Indonesia yakni sebesar 18.481 dolar Amerika Serikat (World Bank, 2020). Selain itu, data dari laman The World Bank pada 2018 menunjukkan 9,8 persen penduduk Indonesia masih berada di bawah garis kemiskinan, sementara Vietnam sebagai peringkat ketiga dengan jumlah penduduk paling banyak di Kawasan Asia Tenggara, hanya 6,7 persen penduduknya yang berada di bawah garis kemiskinan (The World Bank, 2020).

Lembaga Demografi Fakultas Ekonomi Universitas Indonesia (LDFEUI, 2007) menyatakan bahwa pertumbuhan penduduk di suatu wilayah dipengaruhi oleh empat faktor utama demografi, salah satunya adalah kelahiran. Ukuran angka kelahiran total (Total Fertility Rate/TFR) dan pembatasan jumlah kelahiran dengan penggunaan kontrasepsi (Contraceptive Prevalence Rate/CPR) merupakan ukuran fertilitas yang terus dipantau perkembangannya oleh pemerintah untuk mengatasi konsekuensi atas tingginya kelahiran yang akan berdampak pada peningkatan jumlah penduduk. Guna mengatasi permasalahan kependudukan tersebut, pemerintah sejak 1970 melalui Badan Kependudukan dan Keluarga Berencana Nasional (BKKBN) menggagaskan program Keluarga Berencana (KB). Gagasan ini tertuang sebagai target pembangunan internasional pada tujuan pembangunan berkelanjutan nomor tiga (Sustainable Development Goals/SDGs) poin ketujuh, yakni jaminan akses universal terhadap layanan kesehatan seksual dan reproduksi. Gagasan ini juga dituang ke dalam program nasional melalui Rencana Pembangunan Jangka Menengah Nasional (RPJMN) 2015-2019 mengenai turunnya TFR dan meningkatnya CPR.

Fakta bahwa program KB sudah berjalan cukup lama, nyatanya banyak target yang tidak tercapai hingga saat ini. Pertama, TFR Indonesia masih berada pada angka yang stagnan dari tahun 2002 hingga tahun 2012, yakni 2,6 (BKKBN; BPS; Kementerian Kesehatan; USAID, 2018). Kemudian turun pada angka 2,4 di tahun 2017 tapi masih menduduki peringkat kelima dengan TFR tertinggi di ASEAN (International Conference on Population and Development, 2012). Padahal, Singapura saat ini sudah mencapai TFR sebesar 1,2. Kedua, peserta KB aktif baru yang hanya sebesar 57,2 persen masih cukup jauh di bawah targetnya yang sebesar 61,1 persen (BKKBN, 2016). Ketiga, dari seluruh pengguna alat/cara KB, hanya 13,2 persen WUS yang menggunakan Metode Kontrasepsi Jangka Panjang (MKJP) pada 2017, sementara mengacu pada RPJMN 20152019 ditargetkan pada 2016, pengguna MKJP harus mencapai 21,1 persen. BKKBN (2011) mengungkapkan bahwa MKJP merupakan metode kontrasepsi paling efektif dengan tingkat keberhasilan di atas 95 persen. Melihat rendahnya capaian tersebut, penelitian ini bertujuan untuk menganalisis determinan status penggunaan MKJP di Indonesia tahun 2017.

Penelitian ini didasari penelitian sebelumnya yang ditulis oleh Febriana (2018) yang menyatakan beberapa variabel yang memengaruhi status penggunaan MKJP di Indonesia yang hanya dilihat dari sisi wanita, yakni terdiri atas umur, umur kawin pertama, pendidikan, status bekerja, anak lahir hidup, anak masih hidup, dan kepemilikan jaminan kesehatan. Selain itu, 
penelitian lainnya dilakukan Laksmini (2017) menggunakan studi kasus di Pulau Jawa dengan mempertimbangkan karakteristik rumah tangga seperti status sosial ekonomi dan sumber pelayanan KB. Oleh karena itu, penelitian ini dilakukan tidak hanya mengikutsertakan variabel yang dilihat dari sisi wanita dan rumah tangga wanita, tetapi juga dilihat dari sisi dukungan suami.

\section{METODE}

Green (1984) menyatakan bahwa faktor perilaku seseorang dari segi kesehatan dipengaruhi oleh faktor dari diri sendiri (predisposing factors), faktor pemungkin (enabling factors), dan faktor penguat (reinforcing factors). Pertama, faktor predisposisi merupakan faktor yang mendahului perilaku untuk menetapkan pemikiran terdiri atas umur WUS, tingkat pendidikan WUS, status bekerja WUS, umur kawin pertama WUS, dan Anak Lahir Hidup (ALH). Wanita yang berumur lebih dari 35 tahun cenderung untuk menggunakan kontrasepsi yang berefektivitas tinggi karena kemungkinan sudah memiliki anak cukup dan tidak menginginkannya lagi (Yuanti \& Maesaroh, 2019). Selanjutnya, pendidikan memiliki pengaruh positif terhadap pemakaian kontrasepsi, karena berikatan dengan informasi yang diterima dalam memenuhi kebutuhan untuk menunda dan membatasi jumlah anak (Rachmayani, 2015). Status bekerja juga memberikan pengaruh yang signifikan terhadap pemilihan sterilisasi (BKKBN, 1998). Menurut Pandey dan Singh (2015), peningkatan usia saat perkawinan diikuti oleh peningkatan yang sangat signifikan dalam kemungkinan mengguanakan kontrasepsi. Selain itu, terdapat kecenderungan sebesar 2 kali lipat dari seorang wanita yang telah memiliki lebih dari 2 anak untuk menggunakan MKJP dibandingkan dengan wanita yang paling banyak memiliki 2 anak (Weni, Yuwono, \& Idris, 2019).

Kedua, faktor pemungkin menjelaskan kemampuan dari sumber daya yang diperlukan untuk membentuk perilaku, terdiri atas akses informasi KB dan status kesejahteraan rumah tangga. Wanita yang terpapar informasi KB memiliki kecenderungan yang lebih tinggi untuk memakai kontrasepsi dibandingkan wanita yang tidak terpapar informasi KB (Iswarati dalam Handayani, dkk, 2012). Selain itu, wanita yang berada pada tingkat kekayaan yang lebih tinggi memiliki akses yang lebih luas dan pembatasan kelahiran yang lebih baik (Mutombo \& Bakibinga, 2014).

Ketiga, faktor penguat adalah faktor yang menentukan tindakan kesehatan yang dilakukan seseorang dalam mendapatkan dukungan dari keluarga atau tokoh masyarakat. Faktor ini terdiri dari umur suami, tingkat pendidikan suami, pengambil keputusan ber-KB dan klasifikasi wilayah tempat tinggal. Menurut Maryani dalam Puteri, Noor, dan Arifin (2019), dukungan suami mempunyai hubungan yang bermakna dengan penggunaan MKJP. Ditemukan bahwa suami yang berpendidikan tinggi lebih memilih untuk menggunakan kontrasepsi modern (Risky \& Harsanti, 2016). Hasil penelitian di Provinsi Jawa Timur menunjukkan WUS yang bertempat tinggal di daerah perkotaan berpengaruh signifikan terhadap penggunaan Metode Operatif Wanita dibandingkan dengan WUS yang tinggal di daerah perdesaan (Triyanto \& Indriani, 2018).

Selanjutnya, untuk mengukur besarnya hubungan antara variabel-variabel tersebut terhadap penggunaan MKJP dibangun model regresi logistik biner yang mengakomodir penimbang survei (sampling weight). Model regresi logistik biner merupakan model regresi logistik dengan variabel dependen (dinotasikan dengan $Y$ ) dikotomi (memiliki 2 kategori) yang mengikuti distribusi binomial dengan tahapan pembangunan model sebagai berikut (Heeringa, West, \& Berglund, 2010).

Pertama, spesifikasi model dilakukan untuk memilih variabel-variabel independen (yang dinotasikan dengan $X$ ) yang diperkirakan memiliki pengaruh terhadap variabel dependen. Berikut ini merupakan model regresi logistik biner yang akan dibangun.

$$
\pi(\mathbf{x})=\frac{e^{\beta_{0}+\beta_{1} x+\beta_{2} x_{2}+\cdots+\beta_{p} x_{p}}}{1+e^{\beta_{0}+\beta_{1} x+\beta_{2} x_{2}+\cdots+\beta_{p} x_{p}}}
$$

Bentuk $\pi(\mathbf{x})$ ditransformasi dengan transformasi logit guna memperoleh sifat yang linear terhadap paramater, maka persamaan di atas akan menjadi:

$$
g(\mathbf{x})=\operatorname{logit}(\pi(\mathbf{x}))=\ln \left[\frac{\pi(\mathbf{x})}{1-\pi(\mathbf{x})}\right]=\beta_{0}+\beta_{1} x+\beta_{2} x_{2}+\cdots+\beta_{p} x_{p}
$$


Selanjutnya, jika $Y$ dikodekan dengan nilai 0 atau 1 lalu memiliki peluang seperti persamaan (1) akan menghasilkan (untuk mendapatkan nilai $\boldsymbol{\beta}=\left(\beta_{0}, \beta_{1}, \ldots, \beta_{p}\right)$ yang merupakan vektor dari parameter) peluang bersyarat dari munculnya $Y=1$ dengan syarat $\mathbf{x}$, yang dinotasikan $P(Y=1 \mid \mathbf{x})$ . Hal tersebut diikuti dengan nilai dari $1-\pi\left(\mathbf{x}_{i}\right)$ yang merupakan nilai peluang bersyarat dari munculnya $Y=0$ dengan syarat $\mathbf{x}$, dinotasikan $P(Y=0 \mid \mathbf{x})$. Untuk pasangan $\left(\mathbf{x}_{i}, y_{i}\right)$ di mana $y_{i}=1$ , memiliki fungsi likelihood $\pi\left(\mathbf{x}_{i}\right)$ dan untuk pasangan di mana $y_{i}=0$ memiliki fungsi likelihood $1-\pi\left(\mathbf{x}_{i}\right)$, yang mana nilai $\pi\left(\mathbf{x}_{i}\right)$ dihitung saat $\mathbf{x}_{i}$, dan $i$ menandakan observasi ke-1,2, $\ldots, n$. Bila dituliskan, fungsi likelihood untuk pasangan $\left(\mathbf{x}_{i}, y_{i}\right)$ akan membentuk seperti persamaan berikut ini:

$$
\pi\left(\mathbf{x}_{i}\right)^{y_{i}}\left[1-\pi\left(\mathbf{x}_{i}\right)\right]^{1-y_{i}}
$$

Tahap berikutnya adalah estimasi parameter model. Binder dalam Lumley (2004) memperkenalkan metode estimasi Pseudo-Maximum Likelihood Estimation (PMLE). Ketika data diperoleh dari survei kompleks, metode Maximum Likelihood Estimation (MLE) tidak dapat digunakan karena survei kompleks merupakan survei yang mengaplikasikan strata, klaster, unequal sampling, dan finite population (Lumley, 2004). Lumley (2004) menegaskan bahwa melakukan analisis data yang diperoleh dari sampel yang terpilih berdasarkan strata tetapi mengasumsikannya dipilih dengan simple random sampling (SRS) akan membuat standar eror yang dihasilkan overestimate. Selain itu, melakukan analisis yang pemilihan sampelnya menerapkan clustering tetapi mengasumsikannya dengan SRS biasanya akan membuat standar eror yang dihasilkan menjadi underestimate, begitu juga dengan analisis yang dilakukan pada sampel dengan peluang terpilih yang tidak sama, sehingga dibutuhkan sampling weight dalam analisis. Oleh karena itu, fungsi PMLE model regresi logistik biner yang terbentuk adalah:

$$
P L(\boldsymbol{\beta})=\prod_{i=1}^{n}\left\{\pi\left(\mathbf{x}_{i}\right)^{y_{i}}\left[1-\pi\left(\mathbf{x}_{i}\right)\right]^{1-y_{i}}\right\}^{w_{i}}
$$

Untuk mendapatkan nilai estimasi parameter $\boldsymbol{\beta}$, dilakukan dengan memaksimumkan fungsi PMLE pada persamaan (4) menggunakan metode iterasi Newton Raphson kemudian menurunkannya terhadap parameter $\boldsymbol{\beta}$ dan disamadengankan 0 . Selanjutnya, untuk mengestimasi varians-kovarians dari penduga parameter, dilakukan dengan mengaplikasikasikan Taylor Series Linearization (TSL) dengan sandwich-type variance estimator.

Setelah mendapatkan penduga parameter model, dilakukan pengujian kesesuaian model dengan uji F-adjusted test statistic (Archer \& Lemeshow, 2006). Pengujian ini dilakukan untuk mengetahui apakah model yang terbentuk cocok dengan data atau tidak dengan hipotesis nol model cocok dengan data melawan hipotesis model tidak cocok dengan data. Berdasarkan Archer dan Lemeshow (2006), setelah mendapatkan model regresi logistik, diperoleh nilai residual $\hat{r}_{j i}=y_{j i}-\hat{\pi}\left(\mathbf{x}_{j i}\right)$. Dengan menggunakan strategi pengelompokan (Graubard, Korn, \& Midthune, 1997 dalam Archer \& Lemeshow, 2006), seluruh observasi diurutkan ke dalam desil risiko berdasarkan nilai estimasi peluangnya, dan pada tiap desil risiko nilai estimasi peluangnya hampir mendekati total sampling weight.

Selanjutnya, nilai estimasi dari rata-rata residual berdasarkan desil risiko tersebut dilambangkan dengan $\widehat{M}$, misal $\widehat{M}_{1}=\sum_{j} \sum_{i} w_{j i} \hat{r}_{j i} / \sum_{j} \sum_{i} w_{j i}$ untuk 10 persen terendah dari nilai $\hat{r}_{j i}$ sampai ke $\widehat{M}_{10}$ untuk 10 persen tertinggi dari nilai $\hat{r}_{j i}$. Nilai $w_{j i}$ merepresentasikan sampling weight yang terkait dengan residual yang telah diurutkan ke dalam kelompok desil risiko. Estimasi matriks varians-kovarians, $\widehat{V}(\widehat{M})$, diperoleh dengan menggunakan pendekatan first-order Taylor Series Linearization. Karena itu, statistik uji yang digunakan adalah sebagai berikut:

$$
\widehat{Q}_{M}=\frac{f-g+2}{f g} \widehat{M}^{t} \widehat{V}(\widehat{M})^{-1} \widehat{M} \sim F
$$

di mana:

$f=$ Total Primary Sampling Unit (PSU) dikurangi jumlah strata

$g=$ Jumlah kategori yang termasuk dalam hipotesi 
Implementasi dari pengujian statistik ini tersedia di software STATA dengan package svylogitgof. Keputusan gagal tolak $H_{0}$ dapat diambil jika nilai $p-$ value $>\alpha$. Jika gagal tolak $H_{0}$ artinya dengan tingkat signifikansi $\alpha$, model yang diperoleh cocok dengan data (Archer \& Lemeshow, 2006).

Berikutnya, uji signifikansi penduga parameter secara simultan dilakukan untuk menentukan apakah variabel-variabel yang berada dalam model signifikan berpengaruh terhadap variabel dependen secara bersama-sama dengan hipotesis berikut:

$H_{0}: \boldsymbol{\beta}=\mathbf{0}$ (Tidak terdapat pengaruh yang signifikan antara seluruh variabel independen terhadap variabel dependen)

$H_{1}: \boldsymbol{\beta} \neq \mathbf{0}$ (Minimal terdapat satu variabel independen yang berpengaruh signifikan terhadap variabel dependen)

Statistik uji yang digunakan adalah uji adjusted Wald test dengan bentuk di bawah ini:

$$
F=\frac{(s-p+1)}{s p} W
$$

di mana:

$$
W=\widehat{\boldsymbol{\beta}}^{\prime}\left[\widehat{\operatorname{Var}}(\widehat{\boldsymbol{\beta}})_{p \times p}\right]^{-1} \widehat{\boldsymbol{\beta}}
$$

Simbol $\widehat{\boldsymbol{\beta}}$ merupakan vektor dari $p$ koefisien variabel independen dan $\widehat{\operatorname{Var}}(\widehat{\boldsymbol{\beta}})_{p \times p}$ adalah submatriks berbentuk $p \times p$ dari matriks full penduga varians-kovarians parameter. Statistik uji $F$ merupakan pendekatan dari statistik $W$ yang dimodifikasi di mana $s=\left(\sum_{k=1}^{K} m_{k}\right)-K$ yaitu total primary sampling unit (PSU) dikurangi jumlah strata dengan derajat bebas $p$ dan $(s-p+1)$ (Hosmer \& Lemeshow, 2013). Keputusan tolak $H_{0}$ dapat diambil jika nilai $F>F_{(p, s-p+1)}$. Jika tolak $H_{0}$ artinya dengan tingkat signifikansi $\alpha$, minimal terdapat satu variabel independen berpengaruh terhadap variabel dependen.

Selanjutnya, uji signifikansi penduga parameter secara parsial dilakukan untuk menguji pengaruh variabel independen terhadap variabel dependen secara parsial dengan hipotesis:

$H_{0}: \beta_{j}=0$ (Tidak terdapat pengaruh yang signifikan antara variabel independen ke- $j$ terhadap variabel dependen)

$H_{1}: \beta_{j} \neq 0$ (Terdapat pengaruh yang signifikan antara variabel independen ke- $j$ terhadap variabel dependen)

Statistik uji yang digunakan adalah statistik uji $t$ seperti di bawah ini:

$t=\frac{\hat{\beta}_{j}}{\operatorname{se}\left(\hat{\beta}_{j}\right)}$

Statistik uji $t$ mengikuti distribusi Student-t dengan derajat bebas jumlah cluster dikurangi jumlah strata (Heeringa, West, \& Berglund, 2010). Keputusan tolak $H_{0}$ dapat diambil ketika nilai $t>t_{\text {(\#cluster-\#strata) }}$. Jika tolak $H_{0}$, artinya dengan tingkat signifikansi $\alpha$, variabel independen ke- $j$ berpengaruh signifikan terhadap variabel dependen. Dan langkah terakhir adalah penghitungan dan interpretasi nilai odds ratio.

Penelitian ini menggunakan data sekunder berupa raw data dari hasil SDKI 2017 dan shapefile peta Indonesia. Raw data diperoleh dari laman resmi BKKBN yaitu www.sdki.bkkbn.go.id dengan kode dataset IDIR71FL. Data yang dikumpulkan berasal dari responden Wanita Usia Subur (15-49 tahun) yang diwawancarai menggunakan Kuesioner SDKI17-WUS dan SDKI17-RT. Unit analisis penelitian ini adalah WUS berstatus kawin dan sedang menggunakan alat/cara kontrasepsi, yakni sebanyak 19.134 WUS. Sampling weight yang digunakan penelitian ini berasal dari hasil penghitungan pengolah SDKI 2017 dan tersedia pada raw data. Terdapat satu variabel dependen yang digunakan pada penelitian ini, yaitu status penggunaan MKJP, di mana metode KB yang termasuk ke dalam MKJP adalah Intra Uterine Device (IUD), implan, dan metode operatif wanita (MOW) dan selainnya dikategorikan sebagai metode KB nonjangka panjang. Selain itu, terdapat 11 variabel independen yang diperkirakan memengaruhi variabel dependen pada penelitian ini dengan rincian pada Tabel 1 di bawah. 
Tabel 1. Definisi operasional

\begin{tabular}{|c|c|c|c|c|c|}
\hline & Variabel & Keterangan & & Variabel & Keterangan \\
\hline $\mathbf{Y}$ & $\begin{array}{l}\text { Status } \\
\text { Penggunaan } \\
\text { MKJP }\end{array}$ & $\begin{array}{l}0=\text { Tidak } \\
1=\text { Ya }\end{array}$ & \multirow[b]{4}{*}{$\mathbf{x}$} & $\begin{array}{l}\text { Umur Kawin Pertama } \\
\text { WUS }\end{array}$ & Numerik (dalam tahun) \\
\hline \multirow{5}{*}{$\mathbf{x}$} & Umur WUS & $\begin{array}{l}0=\text { Kurang dari } 20 \text { tahun } * \\
1=20-35 \text { tahun } \\
2=\text { Lebih dari } 35 \text { tahun }\end{array}$ & & Anak Lahir Hidup & $\begin{array}{l}0=\text { Kurang dari atau } \\
\text { sama dengan } 2 \text { anak* } \\
1=\text { Lebih dari } 2 \text { anak }\end{array}$ \\
\hline & $\begin{array}{l}\text { Tingkat } \\
\text { Pendidikan } \\
\text { WUS }\end{array}$ & $\begin{array}{l}0=\text { SMP ke bawah } * \\
1=\text { Tamat SMA ke atas }\end{array}$ & & Akses Informasi KB & $\begin{array}{l}0=\text { Tidak pernah } \\
\text { mengakses informasi KB* } \\
1=\text { Mengakses informasi } \\
\text { KB }\end{array}$ \\
\hline & $\begin{array}{l}\text { Status } \\
\text { Bekerja WUS }\end{array}$ & $\begin{array}{l}0=\text { Tidak bekerja* } \\
1=\text { Bekerja }\end{array}$ & & $\begin{array}{l}\text { Pengambil Keputusan } \\
\text { Ber-KB }\end{array}$ & $\begin{array}{l}0=\text { WUS } \\
1=\text { Suami } \\
2=\text { Bersama } \\
3=\text { Lainnya }\end{array}$ \\
\hline & Umur Suami & $\begin{array}{l}0=\text { Kurang dari atau sama } \\
\text { dengan } 30 \text { tahun } * \\
1=\text { Lebih dari } 30 \text { tahun }\end{array}$ & & $\begin{array}{l}\text { Klasifikasi Wilayah } \\
\text { Tempat Tinggal }\end{array}$ & $\begin{array}{l}0=\text { Perdesaan } * \\
1=\text { Perkotaan }\end{array}$ \\
\hline & $\begin{array}{l}\text { Tingkat } \\
\text { Pendidikan } \\
\text { Suami }\end{array}$ & $\begin{array}{l}0=\text { SMP ke bawah } * \\
1=\text { Tamat SMA ke atas }\end{array}$ & & $\begin{array}{l}\text { Status Kesejahteraan } \\
\text { Rumah Tangga }\end{array}$ & $\begin{array}{l}0=\text { Rendah } * \\
1=\text { Menengah } \\
2=\text { Tinggi }\end{array}$ \\
\hline
\end{tabular}

Sumber: SDKI 2017, diolah

Keterangan: *) kategori referensi

Penelitian ini menggunakan analisis deskriptif yang menyajikan hasil pengolahan data mengenai status penggunaan MKJP di Indonesia tahun 2017 berdasarkan tiap-tiap variabel independen. Hasil analisis deskriptif disajikan dalam bentuk tabel dan gambar berupa peta tematik yang diolah dengan aplikasi Microsoft Excel 2016, SPSS 25 student free trial dan QGIS Dekstop 3.4.3. Selanjutnya, untuk mengetahui determinan yang memengaruhi status penggunaan MKJP, dilakukan analisis inferensia dengan membangun model regresi logistik biner yang mengakomodir sampling weight dan diolah menggunakan aplikasi STATA 15 sesuai dengan tahapan yang telah dijelaskan sebelumnya.

\section{HASIL DAN PEMBAHASAN}

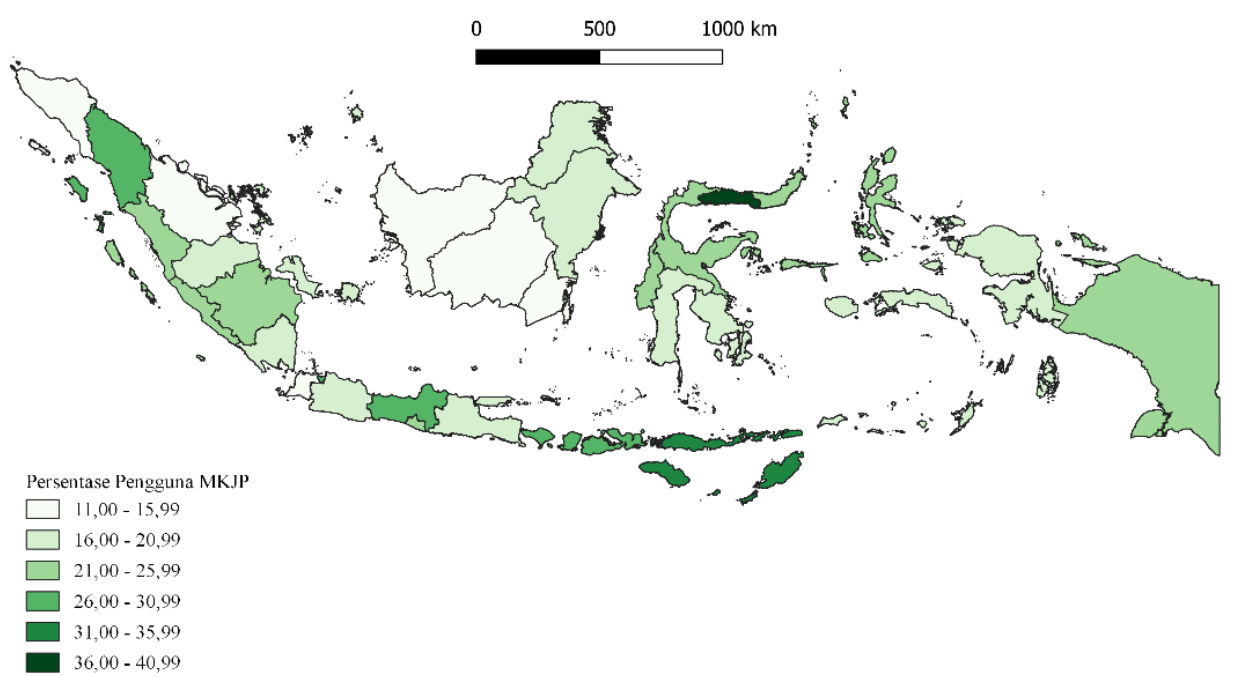

Gambar 1. Persentase Pengguna MKJP berdasarkan Provinsi di Indonesia tahun 2017 
Berdasarkan hasil pengolahan data ditemukan hanya sebesar 21,05 persen WUS yang menggunakan MKJP dan sebesar 78,95 persen WUS menggunakan non-MKJP di Indonesia tahun 2017. Artinya, dari 5 WUS berstatus kawin yang sedang menggunakan alat kontrasepsi, hanya 1 WUS yang menggunakan MKJP. Berikutnya, disajikan peta pada Gambar 1 yang memperlihatkan semakin tua warna yang tampak, semakin tinggi pengguna MKJP di wliayah tersebut. Hasilnya menunjukkan bahwa Provinsi Gorontalo merupakan provinsi dengan persentase pengguna MKJP tertinggi, yakni hampir 2 kali lipat dari rata-rata nasional, sementara Provinsi Banten merupakan provinsi dengan persentase pengguna MKJP terendah yakni hanya sekitar setengah dari rata-rata nasional. Berikut ini disajikan gambaran status penggunaan MKJP berdasarkan variabel independen. Terlihat pula dari gambar tersebut bahwa 3 dari 5 provinsi di Pulau Kalimantan didominasi oleh warna putih wilayahnya. Hal ini menandakan bahwa WUS di Pulau Kalimantan masih didominasi oleh pengguna non-MKJP. Secara rinci ditemukan bahwa Provinsi Kalimantan Selatan dan Kalimantan Tengah merupakan provinsi dengan persentase pengguna MKJP terendah kedua dan ketiga di Indonesia tahun 2017, yakni hanya sekitar setengah dari rata-rata nasional. Selanjutnya disajikan persentase status penggunaan MKJP berdasarkan variabel independen.

Tabel 2. Persentase status penggunaan MKJP berdasarkan variabel independen

\begin{tabular}{|c|c|c|c|c|}
\hline \multirow{2}{*}{ No } & \multirow{2}{*}{\multicolumn{2}{|c|}{ Variabel }} & \multicolumn{2}{|c|}{ Status penggunaan MKJP } \\
\hline & & & Ya & Tidak \\
\hline \multirow{3}{*}{1} & \multirow{3}{*}{ Umur WUS } & $>35$ tahun & 26,0 & 74,0 \\
\hline & & 20-35 tahun & 16,4 & 83,6 \\
\hline & & $<20$ tahun & 6,7 & 93,3 \\
\hline \multirow{2}{*}{2} & \multirow{2}{*}{ Tingkat Pendidikan WUS } & Tamat SMA ke atas & 31,8 & 68,2 \\
\hline & & SMP ke bawah & 19,7 & 80,3 \\
\hline \multirow{2}{*}{3} & \multirow{2}{*}{ Status Bekerja WUS } & Bekerja & 22,5 & 77,5 \\
\hline & & Tidak bekerja & 19,2 & 80,8 \\
\hline 4 & Umur Kawin Pertama WUS & Numerik (dalam tahun) & & \\
\hline \multirow{2}{*}{5} & \multirow{2}{*}{ Anak Lahir Hidup } & $>2$ anak & 28,6 & 71,4 \\
\hline & & $\leq 2$ anak & 16,9 & 83,1 \\
\hline \multirow{2}{*}{6} & \multirow{2}{*}{ Akses Informasi KB } & Mengakses informasi KB & 21,9 & 78,1 \\
\hline & & Tidak mengakses informasi KB & 19,7 & 80,3 \\
\hline \multirow{4}{*}{7} & \multirow{4}{*}{ Pengambil Keputusan Ber-KB } & Suami & 23,4 & 76,6 \\
\hline & & Bersama & 23,3 & 76,7 \\
\hline & & Lainnya & 42,6 & 57,4 \\
\hline & & WUS & 16,6 & 83,4 \\
\hline \multirow{2}{*}{8} & \multirow{2}{*}{ Umur Suami } & $>30$ tahun & 22,6 & 77,4 \\
\hline & & $\leq 30$ tahun & 13,2 & 86,8 \\
\hline \multirow{2}{*}{9} & \multirow{2}{*}{ Tingkat Pendidikan Suami } & Tamat SMA ke atas & 31,3 & 68,7 \\
\hline & & SMP ke bawah & 19,8 & 80,2 \\
\hline \multirow{2}{*}{10} & \multirow{2}{*}{ Klasifikasi Wilayah Tempat Tinggal } & Perkotaan & 23,1 & 76,9 \\
\hline & & Perdesaan & 19,1 & 80,9 \\
\hline \multirow{3}{*}{11} & \multirow{3}{*}{ Status Kesejahteraan Rumah Tangga } & Tinggi & 23,9 & 76,1 \\
\hline & & Menengah & 19,6 & 80,4 \\
\hline & & Rendah & 18,6 & 81,4 \\
\hline
\end{tabular}

Sumber: SDKI 2017, diolah

Berdasarkan Tabel 2, ditemukan hanya seperempat WUS yang berumur di atas 35 tahun yang menggunakan MKJP, setidaknya sepertiga WUS yang tamat SMA ke atas yang menggunakan MKJP, tidak sampai seperempat WUS berstatus bekerja yang menggunakan MKJP, tidak sampai sepertiga dari WUS yang sudah memiliki 2 anak lahir hidup (ALH) yang menggunakan MKJP, dan tidak sampai seperempat WUS yang mengakses informasi KB yang menggunakan MKJP. Hasil yang sedikit berbeda ditemukan pada variabel pengambil keputusan ber-KB. Dari seluruh WUS yang peran pengambil keputusan ber-KB dilakukan baik hanya oleh suami maupun bersama suami, hampir seperempatnya menggunakan MKJP. Hal mengejutkan diperoleh ketika peran pengambil keputusan ber-KB dilakukan oleh kerabat dekat, yakni hampir separuhnya menggunakan MKJP. 
Dari seluruh WUS yang suaminya berumur lebih dari 30 tahun, tidak sampai seperempat WUS menggunakan MKJP. Selain itu, dari seluruh WUS yang suaminya berpendidikan tamat SMA ke atas, setidaknya terdapat sepertiga dari WUS yang menggunakan MKJP. Ditemukan juga, tidak sampai seperempat dari WUS yang tinggal di perkotaan dan hanya sekitar seperempat WUS yang berstatus kesejahteraan tinggi yang menggunakan MKJP. Selanjutnya, berikut ini merupakan hasil pengujian analisis inferensia.

Tabel 3. Hasil penghitungan uji kesesuaian model dan uji signifikansi penduga parameter secara simultan

\begin{tabular}{|c|c|c|c|c|c|}
\hline Uji Statistik & $\begin{array}{c}\text { Nama } \\
\text { Statistik Uji }\end{array}$ & $\begin{array}{c}\text { Nilai } \\
\text { Statistik Uji }\end{array}$ & $p$-value & $\begin{array}{c}\text { Nilai Statisik } \\
\text { Tabel }\end{array}$ & Keputusan \\
\hline $\begin{array}{c}\text { Uji Kesesuaian } \\
\text { Model }\end{array}$ & $\begin{array}{l}\text { F-adjusted } \\
\text { test statistic }\end{array}$ & 1,036 & 0,408 & $F_{(9,1.889)}=1,883$ & Gagal Tolak $\mathrm{H}_{0}$ \\
\hline $\begin{array}{c}\text { Uji Signifikansi } \\
\text { Penduga Parameter } \\
\text { secara Simultan }\end{array}$ & $\begin{array}{l}\text { Adjusted } \\
\text { wald test } \\
\text { statistic }\end{array}$ & 34,22 & 0,000 & $\boldsymbol{F}_{(\mathbf{1 6 , 1 . 8 8 2 )}}=1,683$ & Tolak $\mathrm{H}_{0}$ \\
\hline
\end{tabular}

Untuk uji kesesuaian model, dari Tabel 3 diperoleh nilai statistik uji sebesar 1,036 yang menunjukkan nilai yang lebih kecil dari nilai statistik tabel yaitu 1,883. Dengan demikian, keputusan yang diambil adalah gagal tolak $H_{0}$. Artinya, dengan tingkat signifikansi 5 persen, model yang diestimasi sesuai dengan data. Untuk pengujian signifikansi penduga parameter secara simultan diperoleh nilai statistik uji sebesar 34,22 yang lebih besar dari nilai statistik tabel yaitu 1,683. Dengan demikian, keputusan yang diambil adalah tolak H0. Artinya, dengan tingkat signifikansi 5 persen dapat dikatakan bahwa minimal ada satu variabel independen yang memengaruhi status penggunaan MKJP.

Tabel 4. Hasil penghitungan uji signifikansi penduga parameter secara parsial dan nilai odds ratio.

\begin{tabular}{|c|c|c|c|c|c|}
\hline Variabel Independen & $\hat{\beta}$ & $\operatorname{se}(\hat{\beta})$ & $t$ & $p$-value & Odds Ratio \\
\hline Konstanta & $-3,298$ & 0,317 & $-10,39$ & $0,000 *$ & 0,037 \\
\hline \multicolumn{6}{|l|}{ Umur WUS } \\
\hline 1. UmurWUS(1) & 0,643 & 0,291 & 2,21 & $0,027^{*}$ & 1,903 \\
\hline 2. UmurWUS(2) & 0,978 & 0,302 & 3,24 & $0,001 *$ & 2,660 \\
\hline \multicolumn{6}{|l|}{ Tingkat pendidikan WUS } \\
\hline 1. PendidikanWUS(1) & 0,428 & 0,076 & 5,65 & $0,000 *$ & 1,534 \\
\hline \multicolumn{6}{|l|}{ Status bekerja WUS } \\
\hline 1. BekerjaWUS(1) & 0,040 & 0,049 & 0,81 & 0,416 & 1,040 \\
\hline \multicolumn{6}{|l|}{ Umur kawin pertama WUS } \\
\hline 1. UmurKawinPertama & 0,013 & 0,006 & 2,16 & $0,031 *$ & 1,013 \\
\hline \multicolumn{6}{|l|}{ Anak Lahir Hidup } \\
\hline 1. AnakLahirHidup(1) & 0,553 & 0,054 & 10,26 & $0,000^{*}$ & 1,739 \\
\hline \multicolumn{6}{|l|}{ Akses informasi KB } \\
\hline 1. AksesInformasiKB(1) & 0,124 & 0,049 & 2,52 & $0,012 *$ & 1,132 \\
\hline \multicolumn{6}{|l|}{ Pengambil keputusan ber-KB } \\
\hline 1. PengambilKeputusanKB(1) & 0,366 & 0,090 & 4,06 & $0,000 *$ & 1,442 \\
\hline 2. PengambilKeputusanKB(2) & 0,368 & 0,050 & 7,28 & $0,000^{*}$ & 1,444 \\
\hline 3. PengambilKeputusanKB(3) & 1,513 & 0,332 & 4,55 & $0,000 *$ & 4,539 \\
\hline \multicolumn{6}{|l|}{ Umur suami } \\
\hline 1. UmurSuami(1) & 0,193 & 0,077 & 2,51 & $0,012 *$ & 1,213 \\
\hline \multicolumn{6}{|l|}{ Tingkat pendidikan suami } \\
\hline 1. PendidikanSuami(1) & 0,230 & 0,076 & 3,04 & $0,002 *$ & 1,259 \\
\hline \multicolumn{6}{|l|}{ Klasifikasi wilayah tempat tinggal } \\
\hline 1. KlasifikasiWilayahTinggal(1) & 0,090 & 0,060 & 1,49 & 0,137 & 1,094 \\
\hline \multicolumn{6}{|l|}{ Status kesejahteraan rumah tangga } \\
\hline 1. WealthIndex(1) & 0,018 & 0,068 & 0,27 & 0,788 & 1,018 \\
\hline 2. WealthIndex(2) & 0,036 & 0,064 & 0,55 & 0,580 & 1,036 \\
\hline
\end{tabular}

Sumber: Output pengolahan STATA 15

Keterangan: ${ }^{*}$ ) signifikan pada $\alpha=5 \%, t_{1.897}=1,645$ 
Berdasarkan Tabel 4, ditemukan bahwa variabel umur WUS, tingkat pendidikan WUS, umur kawin pertama WUS, Anak Lahir Hidup (ALH), pengambil keputusan ber-KB, akses informasi KB, umur suami, dan tingkat pendidikan suami memiliki nilai statistic uji yang lebih besar dari statistik tabel yakni 1,645. Maka, keputusan yang diambil adalah tolak H0. Artinya variabel tersebut berpengaruh signifikan positif terhadap status penggunaan MKJP. Dengan demikian, terbentuk model regresi logistik biner yang mengakomodir penimbang survei sebagai berikut.

$$
\begin{aligned}
\hat{g}(x)=-3,298 & +0,643 \text { UmurWUS }(1)^{*}+0,978 U \text { murWUS }(2)^{*}+0,428 \text { PendidikanWUS }(1)^{*} \\
& +0,040 \text { BekerjaWUS }(1)+0,013 \text { UmurKawinPertama }+0,553 \text { AnakLahirHidup }(1)^{*} \\
& +0,124 \text { AksesInformasiKB }(1)^{*}+0,366 \text { PengambilKeputusanKB }(1)^{*} \\
& +0,368 \text { PengambilKeputusanKB }(2)^{*}+1,513 P \text { engambilKeputusanKB }(3)^{*} \\
& +0,193 \text { UmurSuami }(1)^{*}+0,230 \text { PendidikanSuami }(1)^{*} \\
& +0,090 \text { KlasifikasiWilayahTinggal }(1)+0,018 W \text { ealthIndex }(1) \\
& +0,036 \text { WealthIndex }(2)
\end{aligned}
$$

Dari hasil pembangunan model tersebut menunjukkan bahwa semakin tua seorang WUS, semakin besar kecenderungannya untuk menggunakan MKJP. Hal ini dikarenakan penggunaan MKJP yang sifatnya cenderung permanen dibandingkan dengan penggunaan non-MKJP membuat WUS harus mempertimbangkan banyak hal, salah satunya keinginan untuk tidak memiliki anak lagi di kemudian hari setelah penggunaan MKJP dilakukan. Hal menarik berikutnya ditemukan bahwa semakin tinggi pendidikan WUS, semakin besar kecenderungannya untuk menggunakan MKJP, karena pendidikan berkaitan erat dengan kemampuan untuk menelaah informasi yang dimiliki seorang WUS.

Selanjutnya ditemukan bahwa peningkatan 1 tahun umur kawin pertama WUS memberikan hasil yang signifikan terhadap status penggunaan MKJP. Selain itu, WUS yang sudah memiliki lebih dari 2 anak juga memiliki kecenderungan yang lebih besar untuk menggunakan MKJP dibandingkan ketika WUS masih memiliki kurang dari atau sama dengan 2 anak. WUS yang mengakses informasi KB juga berpengaruh signifikan terhadap status penggunaan MKJP dibandingkan dengan WUS yang tidak mengakses informasi KB. Hal menarik lainnya ditemukan bahwa peran pengambil keputusan yang dilakukan selain oleh suami dan bersama (WUS dan suaminya) memberikan kecenderungan yang hampir 4,5 kali lipat untuk mampu membuat WUS menggunakan MKJP dibandingkan ketika WUS sendiri yang mengambil keputusan untuk menggunakan KB. Berikutnya, melihat pentingnya peran suami dalam pengambilan keputusan berKB dapat dilihat juga dari sisi umur suami. Semakin tinggi umur suami, semakin besar kecenderungan untuk mendapati istrinya menggunakan MKJP. Selain itu, ditemukan bahwa semakin tinggi pendidikan suami semakin besar kecenderungan untuk mendapati istrinya menggunakan MKJP.

\section{KESIMPULAN}

Berdasarkan hasil yang telah dijelaskan di atas, disimpulkan bahwa pengguna MKJP di Indonesia tahun 2017 masih sedikit di mana Provinsi Gorontalo adalah provinsi dengan persentase pengguna MKJP tertinggi dan Provinsi Banten adalah provinsi dengan persentase pengguna MKJP terendah. Selain itu, ditemukan bahwa umur WUS, tingkat pendidikan WUS, umur kawin pertama WUS, Anak Lahir Hidup (ALH), akses informasi KB, pengambil keputusan ber-KB, umur suami dan tingkat pendidikan suami berpengaruh signifikan terhadap status penggunaan MKJP di mana pengambil keputusan ber-KB yang dilakukan selain oleh suami ataupun WUS bersama suaminya menunjukkan kecenderungan yang paling besar untuk mampu membuat WUS menggunakan MKJP. Dari kesimpulan tersebut, peneliti mengajukan saran agar pemerintah terkait, khususnya BKKBN Provinsi Banten, supaya lebih mencari cara yang memasyarakatkan informasi mengenai MKJP. Selain itu untuk pemerintah secara umum dapat meningkatkan ketersediaan informasi dengan melakukan segmentasi peserta yakni pada WUS yang berumur lebih dari 30 tahun atau sudah memiliki 2 anak. 


\section{DAFTAR PUSTAKA}

Archer, K. J. dan Lemeshow, S. (2006). Goodness-of-fit test for a logistic regression model fitted using survey sample data. The Stata Journal, 6(1), 97-105.

BKKBN. (1998). Faktor-faktor Sosial Budaya yang Memengaruhi Pemakaian Kontrasepsi Mantap Wanita (MOW) dan Kontrasepsi Mantap Pria (MOP) di Jawa Barat dan Nusa Tenggara Barat. Kerjasama LDUIPULDU BKKBN.

BKKBN. (2011). Pedoman Pelaksanaan Pelayanan KB Metode Kontrasepsi Jangka Panjang (MKJP). BKKBN.

BKKBN, BPS, Kementerian Kesehatan, dan USAID. (2018). Survei Demografi dan Kesehatan Indonesia 2017. BKKBN.

Febriana, N. dan Aloysius, S. (2018). Variabel-variabel yang Memengaruhi Penggunaan MKJP pada WUS Kawin di Indonesia tahun 2017. Skripsi Politeknik Statistiika STIS. Jakarta. $100 \mathrm{hlm}$.

Green, L. W. (1984). Modifying and Developing Health Behavior. Annu Rev. Public Health, 5, 215-236.

Handayani, L., Suharmiati, Hariastuti, I., dan Latifah, C. (2012). Peningkatan Informasi tentang KB: Hak Kesehatan Reproduksi yang Perlu Diperhatikan oleh Program Pelayanan Keluarga Berencana. Buletin Penelitian Sistem Kesehatan, 289-297.

Heeringa, Steven G., West, Brady T., Berglund, Patricia A. (2010). Applied Survey Data Analysis. Taylor and Francis Group, LLC.

Hosmer, Jr. D. W., Lemeshow, S., Sturdivant, R. X. (2013). Applied Logistic Regression. John Wiley \& Sons Inc.

International Conference on Population and Development. (2012). Country Implementation Profile. ICPD Beyond 2014. UNFPA. Cited in https://www.unfpa.org/icpd/global-survey. [1 Desember 2019]

Laksmini, P. (2017). Faktor-faktor yang Berhubungan dengan Penggunaan Metode Kontrasepsi Jangka Panjang (MKJP) di Pulau Jawa (Analisis Data SDKI 2012). Journal of Health Sciences Persada Husada Indonesia, 4(12), 11-24.

LDFEUI. (2007). Dasar-dasar Demografi (Introduction to Demography). Salemba 4 dan Lembaga Demografi FE UI.

Lumley, T. (2004). Analysis of complex survey samples. Journal of Statistical Software, 9(8), 1-19.

Mutombo, N. dan Bakibinga, P. (2014). The effect of joint contraceptive decisions on the use of Injectables, Long-Acting and Permanent Methods (ILAMPS) among married female (15-49) contraceptive users in Zambia: a cross-sectional study. Reproductive Health, 11(51), 1-8.

Pandey, A. and Singh, K. K. (2015). Contraeptive use before first pregnancy by women in India (2005-2006): determinants and differentials. BMC Publlic Health. Cited in https://bmcpublichealth.biomedcentral.com/articles/10.1186/s12889-015-2652-y. [25 Desember 2015]

Puteri, N. K., Noor, M. S., dan Arifin, S. (2019). Hubungan Dukungan Suami dan Pola Komunikasi Suami-Istri dengan Penggunaan MKJP. Homeostatis, 2(1), 147-154.

Rachmayani, A. N. (2015). Faktor-faktor yang Berhubungan dengan Perilaku Penggunaan Kontrasepsi pada Wanita Usia Subur (WUS) di Provinsi Sumatera Utara (Data SDKI Tahun 2012). Skripsi Universitas Islam Negeri Syarif Hidayatullah. Jakarta. 119 hlm.

RI (Republik Indonesia). (2014). Rencana Pembangunan Jangka Menengah Nasional 2015-2019 Buku I Agenda Pembangunan Nasional. Kementerian Perencanaan Pembangunan Nasional/Badan Perencanaan Pembangunan Nasional. Jakarta.

Risky dan Harsanti, T. (2016). Pengaruh Faktor Pasangan Terhadap Penggunaan Metode Kontrasepsi IUD (Intra Uterine Device) di Indonesia (Analisis Data SDKI Tahun 2012). Jurnal IImiah WIDYA Kesehatan dan Lingkungan, 1(2), 128-134.

Triyanto, L. dan Indriani, D. (2018). Faktor yang Mempengaruhi Penggunaan Jenis Metode Kontrasepsi Jangka Panjang (MKJP) pada Wanita Menikah Usia Subur di Provinsi Jawa Timur. The Indonesian Journal Public Health, 13(2), 244-255.

United Nations Development Programme. (2020). Human Development Reports. UNDP. Cited in http://hdr.undp.org/en/countries. [6 Januari 2020]

Weni, L., Yuwono, M., dan Idris, H. (2019). Determinan Pemilihan Metode Kontrasepsi Jangka Panjang pada Akseptor KB Aktif di Puskesmas Pademaran. Scientific Periodical of Public Health and Coastal Health, $1(1), 9-16$.

World Bank. (2020). The World Bank Data. The World Bank. Cited in https://data.worldbank.org/indicator/NY.GDP.PCAP.PP.CD. [6 Januari 2020]

World Bank. (2020). The World Bank Data. The World Bank. Cited in https://data.worldbank.org/country. [1 Juni 2020]

Yuanti, Y. dan Maesaroh. (2019). Determinan Pemilihan Metode Kontrasepsi Jangka Panjang (MKJP) Pada Wanita Usia Subur. Jurnal IImiah IImu Kesehatan: Wawasan Kesehatan, 5(2), 154-161. 